Article

\title{
Evaluating the Effectiveness of Urban Hedges as Air Pollution Barriers: Importance of Sampling Method, Species Characteristics and Site Location
}

\author{
Tijana Blanuša ${ }^{1,2, *}$, Zeenat Jabeen Qadir ${ }^{2,+}\left(\mathbb{D}\right.$, Amanpreet Kaur $^{3}$, James Hadley ${ }^{2}$ \\ and Mark B. Gush ${ }^{1}$ (D) \\ 1 Science and Collections Division, Royal Horticultural Society, Wisley, Woking GU23 6QB, UK; \\ markgush@rhs.org.uk \\ 2 School of Agriculture, Policy and Development, University of Reading, Reading RG6 6AS, UK; \\ Zeenat.Qadir@naturalengland.org.uk (Z.J.Q.); j.hadley@reading.ac.uk (J.H.) \\ 3 Chemical Analysis Facility, School of Chemistry, Food and Pharmacy, University of Reading, \\ Reading RG6 6AP, UK; amanpreet.kaur@reading.ac.uk \\ * Correspondence: tijanablanusa@rhs.org.uk \\ † Current address: Natural England, North Gate House, 21-23 Valpy Street, Reading RG1 1AF, UK.
}

Received: 7 July 2020; Accepted: 25 September 2020; Published: 1 October 2020

\begin{abstract}
Urban hedgerows can act as barriers to roadside particulate air pollution, but details on methodologies to quantify pollutant capture, most efficient species to use, and practical planning advice are still evolving. We aimed to compare three widely used approaches to quantify particulate accumulation and deposition, and to ascertain the most cost-effective and robust approach for the rapid screening of various types of hedges. Secondly, using the most efficient methodology, we screened the summertime deposition of particulates on roadside hedges in Reading (UK), not just on species with differing leaf surface characteristics, but also along a transect of the hedge depth. Finally, we also compared particles' capture by hedge leaf surfaces in locations with different traffic intensities, to try and ascertain the extent of reduction of particles' concentration in various hedge types and urban locations. Results suggest that the gravimetric determination of particulate capture was most rapid and cost-effective, while being least technically demanding. We confirmed that hairy and more complex leaves captured most particulates, particularly in the $>10 \mu \mathrm{m}$ range. However, species choice only had a significant impact on the extent of capture on major roads, where the pollutant concentrations were highest. Furthermore, only hedge depths in excess of $2 \mathrm{~m}$ were found to noticeably reduce the concentration of fine particles in species with less capacity for particulates' capture. Findings complement the growing body of knowledge to guide urban and landscape planners in choosing the most appropriate species to mitigate air quality in various urban contexts.
\end{abstract}

Keywords: Cotoneaster; Crataegus; heavy metals; particulate matter; Thuja

\section{Introduction}

Outdoor air pollution, both gaseous and airborne particulate matter, is a concern in urban areas globally. It causes an array of health issues and is found to be responsible for a significant number of premature deaths [1,2]. Vehicle exhaust emissions primarily, but also re-suspended soil dust, tyre, brake or other vehicle wear particles are the major sources of lead, iron, and magnetic loadings on roadside tree leaves [3]. Vegetation has the ability to accumulate airborne particulate matter (PM) by interception, impaction, and/or sedimentation (thus decreasing its concentrations in the air), more effectively than other exposed surfaces [4]. Consequently, there has been much research on the effectiveness of urban vegetation, initially mainly trees, in the removal of gaseous and particulate 
pollution [5-7]. However, over the last decade, a picture has begun to emerge around linear and more upright vegetation (green walls and facades, hedgerows) providing more overall benefit for the removal of PM, particularly in urban street canyon situations [8,9]. This is particularly relevant in the context of PM pollutant concentrations being highest closer to the traffic-related source/ground at $0.3 \mathrm{~m}$ (i.e., small child height) compared to 1.5-2 m (adult head height) [3].

\subsection{Sampling Methods}

Accurate quantification of the levels of PM capture by vegetative barriers is critical if assessments are to be credible, scalable, and of practical use. However, methodologies used to determine PM removal by vegetative barriers can vary widely, depending on resources available and the scale of impact being assessed. Some studies quantify the impact of vegetation by determining concentration of (pollutant) particles in front and behind vegetation, assuming that the difference is due to plant choices/barrier design (e.g., [10]). Others quantify the leaf-level deposition of particles or uptake of elements by different species, at more and less polluted sites, with the assumption that when deposition and plant uptake are higher, the impact on air quality will be greater/positive. For these, a number of different approaches are used in the literature for monitoring of leaf-level deposition and removal of pollutants. Such approaches include particle size distribution analysis by means of scanning electron microscopy (SEM) and image analysis software (e.g., [11-13]); gas chromatography-mass spectrometry (GC-MS) analysis of leaf tissue for the monitoring of accumulation of chemical elements relating to sources of pollution (e.g., [14,15]); Fourier transformed infrared (FTIR) spectra assessments (e.g., [16]); biomagnetic monitoring (e.g., [3,17]), and gravimetric methods (e.g., $[9,18,19])$. Direct comparison of these methods may not always be possible as they measure different attributes of PM (e.g., composition, number, or mass). However, general trends are discernable across multiple techniques, and use of a number of techniques simultaneously helps elucidate various aspects of the elements' and particles' uptake/deposition [20].

Tiwary et al. [21] tested two sampling methods for assessing the effectiveness of a hawthorn hedge as a vegetative barrier for ambient PM with an aerodynamic diameter smaller than $10 \mu \mathrm{m}$ (PM10). FTIR spectra of samples were used to assess absorbance of sulfate, nitrate, ammonium, aliphatic carbon-hydrogen, and carbonyl functional groups. This was compared to calculations from gravimetric measurements which showed that the hedge captured particulate matter (PM10) mass with a collection efficiency of $34 \%$ on average. Their FTIR results suggested that individual functional groups might exhibit different behaviours in the hedge, but they concluded that further method development and sampling was necessary to calculate functional group results with more confidence. More recently, Castanheiro et al. [20] argued that simultaneous use of multiple screening approaches (in their experiment: elemental analysis, magnetic monitoring, and SEM) is required to better understand the complex process of particles' accumulation on leaf surfaces. Other factors likely to influence the reliability and reproducibility of any sampling method are levels of replication and statistical robustness, the consistency of the sampling strategy, and scaling up approaches. Factors such as time of year (seasonality, [22]), meteorological variables (wind direction, wind speed, [23]), rainfall duration intensity and frequency [13], and anthropogenic impacts (e.g., pruning which influences shape, density and size of the canopy, [24]) will all impact the sampling process irrespective of the technique used.

Financial cost, facilities and time required to implement a particular method vary widely. Utilising links with the gardening advisory service of the largest UK gardening charity (Royal Horticultural Society, RHS) providing gardening and plant species choice information to amateur gardeners, we explored the most time- and cost-effective, reproducible way to analyse larger numbers of leaf samples for their capacity to capture airborne particulate pollutants or their proxies. The intention was to find a rapid and cost-effective method of screening large numbers of plant species (predominantly hedges) used in domestic front gardens, as a barrier to traffic-related pollution. The objective was to enable the RHS to provide reliable information on the capacity for plant species to remove particulate pollutants, to its members and the gardening public with an interest in pollutant 
screening properties of linear street vegetation. We chose to compare and evaluate three methods, namely: (1) biomonitoring of heavy metals in leaf tissues by GC-MS analysis (due to the possibility of outsourcing the analysis to an external commercial analysis service, thus providing time savings); (2) microscopic analysis of particles (due to access to the technology in-house and it being the most direct way of discriminating particle sizes and quantifying the particle numbers); and (3) gravimetric techniques (due to its low cost and minimal requirements for specialist facilities and equipment).

\subsection{Plant Species Characteristics}

Quantifications of PM capture have previously been carried out on various types of green infrastructure, namely: green walls [25], green roofs [26], and roadside vegetation, including trees [18], hedgerows [10,27], and even herbaceous roadside plants [28]. Following the early work by Beckett et al. [29], studies have begun to provide detail around which leaf characteristics are linked with the better trapping and retention of PM in various size classes [12,18,23,30]. A recent review of vegetative barriers as a form of green infrastructure developed recommendations on plant selection based on data compiled for 12 influential traits for 61 tree species [31]. The traits that are repeatedly emerging as useful for leaf-level particulate capture and retention include presence of leaf hairs (trichomes), scales, ridges and generally rough epidermal surfaces, along with canopy size (i.e., larger leaf area index and canopy density) [19,31]. More detailed information is beginning to emerge on the importance of the length and density of hairs, their location on the leaf (ab-vs. adaxial), as well as leaf thickness (i.e., specific leaf area) on leaves' capacity to capture particles [32]. Greater capacity of leaf surfaces to trap and retain particles is seen as a positive trait, but the need for the canopy to avoid the 'saturation' of surfaces and 'regenerate' this capacity by effective flushing from rain, is also acknowledged [13]. It had been suggested that a height of $1.5-2 \mathrm{~m}$ and a width of at least $1 \mathrm{~m}$ is required for a hedge or other vegetative barrier to provide significant reduction in particulate matter concentrations behind it $[10,15]$, but specific city-planning and plant management guidance is yet to be established in this respect.

\subsection{Location}

Location of study sites, particularly in relation to traffic routes, will have a significant impact on the quantity of particles that are available to be captured on plant surfaces. Clearly, sites in close proximity to roads and routes with heavy traffic will be more exposed and accumulate higher concentrations of particles and compounds (e.g., [33,34]), compared to those shielded by barriers (such as fences and buildings) and further away from pollution sources [35]. Furthermore, road traffic usually contributes to higher levels of heavy metal pollution than rail transport, with resultant impacts on levels of accumulation within plant tissues [36]. What is less understood, however, is the importance of plant/hedge species choice in various traffic conditions. Presumably, species with an increased capacity for PM capture (those with large canopies and ovate hairy leaves for example) would be advantageous in situations where high levels of airborne pollution are present. But do those structural advantages become less significant in locations with lower background PM levels? Understanding this could inform our planting decisions in various urban locations, depending on their proximity to pollutant sources.

The aims of this study were therefore:

1. To compare three techniques for their cost-effectiveness and consistency in quantifying pollutant capture by roadside hedge species with different leaf structural properties.

2. To assess hedge species differences, and associated leaf structural properties, in their capacity to sequester various forms of roadside pollution (metals and PM).

3. To compare the importance of hedge species differences in several traffic intensity scenarios. 


\section{Materials and Methods}

\subsection{Study Sites}

The study was carried out in the form of three experiments (Table 1) at four locations within the town of Reading, UK (Figure 1). The location of the site for experiments 1 and 2 was a major road (London St., A327, Reading, RG1 4PS, grid reference 51.453711, -0.978180) (Figure 2). Another major road (Inner Distribution Road, A329, Reading, grid reference 51.452548, -0.968159) (Figure 3), together with a site alongside a minor road (Napier Rd., Reading, grid reference 51.459086, -0.959791) (Figure 4) and a control site away from traffic (University of Reading, Harris Gardens, grid reference 51.435737, -0.939814) (Figure 5), all made up the sites for experiment 3.

Table 1. Summary of experimental context and methodologies. * Apart from Taxus, see the microscopy section in the body of M\&Ms.

\begin{tabular}{|c|c|c|c|}
\hline & $\begin{array}{l}\text { Experiment } 1-\text { Determination of } \\
\text { Leaf Heavy Metal Concentrations }\end{array}$ & $\begin{array}{l}\text { Experiment 2-Determination of } \\
\text { Particulate Numbers on } \\
\text { Leaf Surfaces }\end{array}$ & $\begin{array}{c}\text { Experiment 3-Determination of Particulate } \\
\text { Weight in Two Particulate Size Classes, } \\
\text { in Three Locations }\end{array}$ \\
\hline Location & $\begin{array}{l}\text { Major road-London St, A327, } \\
\text { Reading (Figure 2) }\end{array}$ & $\begin{array}{l}\text { Major road-London St, A327, } \\
\text { Reading (Figure 2) }\end{array}$ & $\begin{array}{c}\text { Major road-Inner Distribution Road, } \\
\text { A329, Reading } \\
\text { Minor road-Napier Rd. } \\
\text { No road-University of Reading, } \\
\text { Harris Gardens (Figures 3-5) }\end{array}$ \\
\hline $\begin{array}{l}\text { Arrangement and } \\
\text { distance of hedge } \\
\text { from the road }\end{array}$ & $\begin{array}{l}\text { Plants in individual containers } \\
\text { by the roadside. } \\
1 \mathrm{~m} \\
\end{array}$ & $\begin{array}{l}\text { Same as in Experiment } 1 . \\
1 \mathrm{~m}\end{array}$ & $\begin{array}{l}\text { A full hedgerow in the ground } \\
9 \mathrm{~m} \text { from major road, } 3 \mathrm{~m} \text { from minor road } \\
100+\mathrm{m} \text { in 'no road' scenario }\end{array}$ \\
\hline Hedge species & $\begin{array}{c}\text { Cotoneaster franchetii } \\
\text { Crataegus monogyna } \\
\text { Ligustrum ovalifolium 'Aureum' } \\
\text { Photinia x fraseri 'Red Robin' } \\
\text { Taxus baccata }\end{array}$ & Same as in Experiment 1 & $\begin{array}{l}\text { Acuba japonica } \\
\text { Cotoneaster franchetii } \\
\text { Crataegus monogyna } \\
\text { Thuja plicata }\end{array}$ \\
\hline Sampling date & 12 July 2016, after 9 rain-free days & $\begin{array}{l}11 \text { October 2016, after } 9 \\
\text { rain-free days }\end{array}$ & $\begin{array}{l}6 \text { June } 2019 \text { after } 8 \text { rain-free days (Table } 4 \text { ) } \\
8 \text { July 2019, after } 12 \text { rain-free days (Table } 5 \text { ) }\end{array}$ \\
\hline Sampling approach & $\begin{array}{l}\text { 4x samples, of each species, approx. } \\
200 \mathrm{~cm}^{2} \text { per sample of leaves, } \\
\text { front of the hedge }\end{array}$ & $\begin{array}{l}5 x \text { samples, of each species, sample } \\
\text { approx. } 50 \mathrm{~cm}^{2} \text { per sample, front of } \\
\text { the hedge. Then } 5 \text { leaves in each } \\
\text { sample * assessed microscopically, } \\
\text { in } 2 \text { positions per leaf. }\end{array}$ & $\begin{array}{l}\text { 3-4x samples, of each species, approx. } 200 \mathrm{~cm}^{2} \\
\text { per sample of leaves, front and back of the hedge }\end{array}$ \\
\hline Analysis Technique & GC-MS analysis [15] & $\begin{array}{l}\text { Scanning electron } \\
\text { microscopy-SEM [11] }\end{array}$ & $\begin{array}{c}\text { Leaf washing and sequential } \\
\text { filtration/gravimetric method }[19,22]\end{array}$ \\
\hline
\end{tabular}
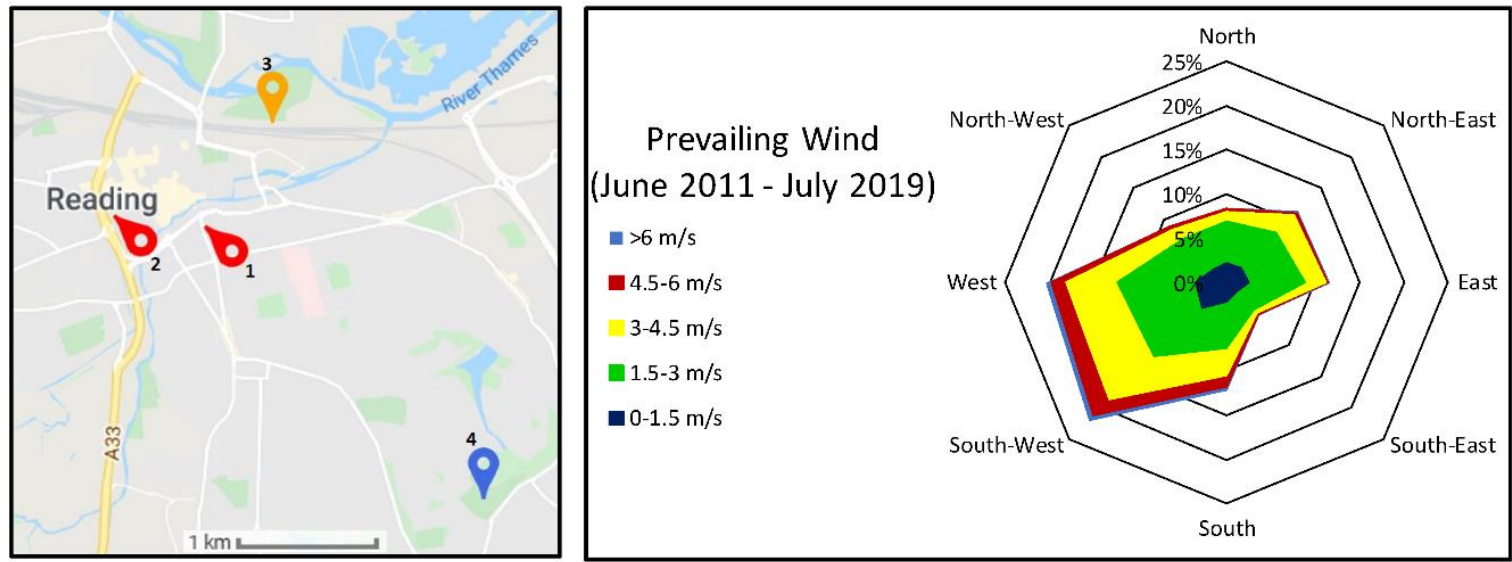

Figure 1. Location of sampling sites within central Reading (UK): Red 1 \& 2-major roads, Orange 3-minor road, Blue 4-Harris Garden (control), and corresponding wind rose indicating prevailing wind conditions. 


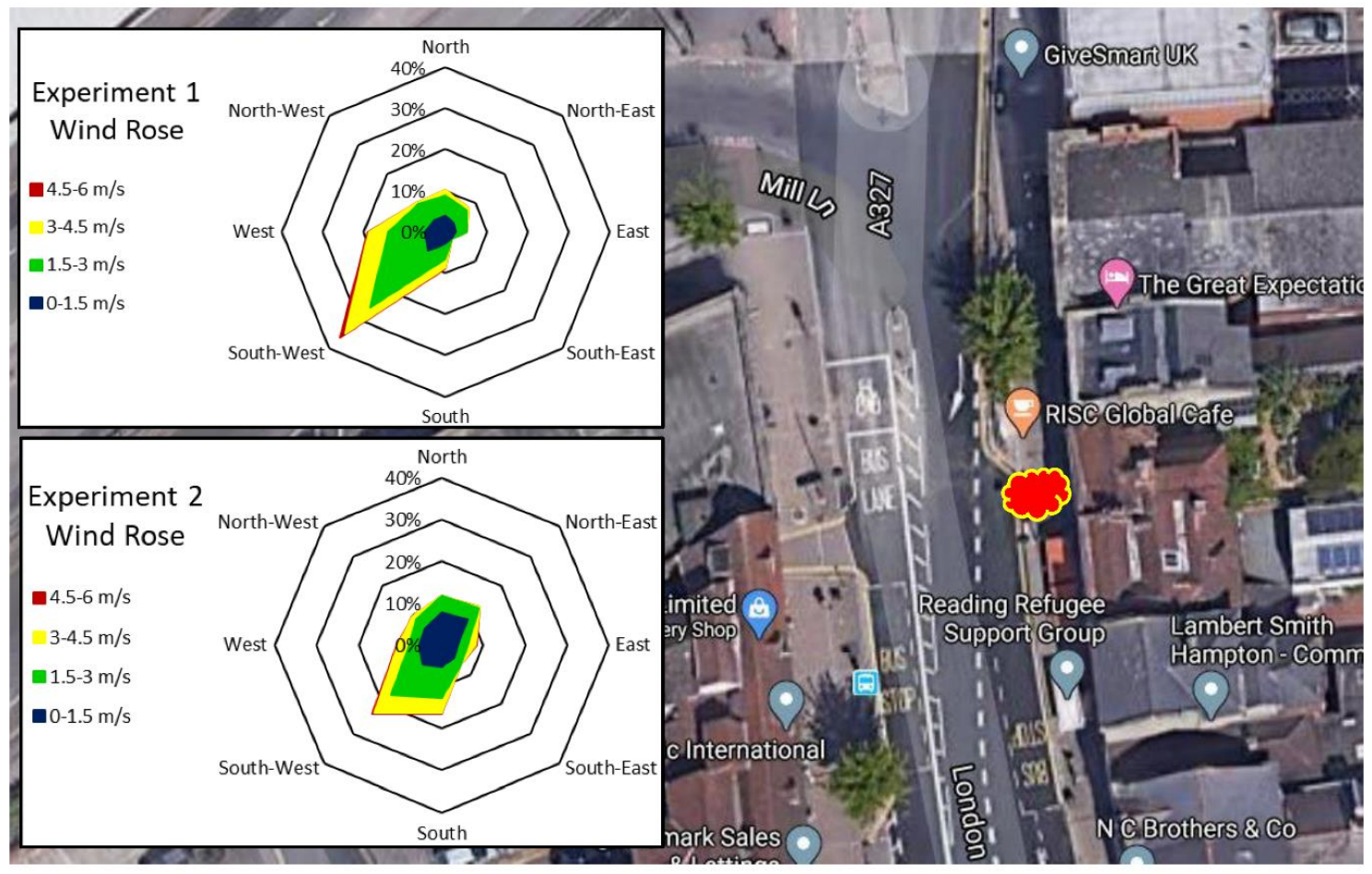

Figure 2. Location of sampling site on a major road used for Experiments 1 and 2, and corresponding wind roses indicating prevailing wind conditions a month prior to sampling. This site corresponds to red location marker 1 in Figure 1.

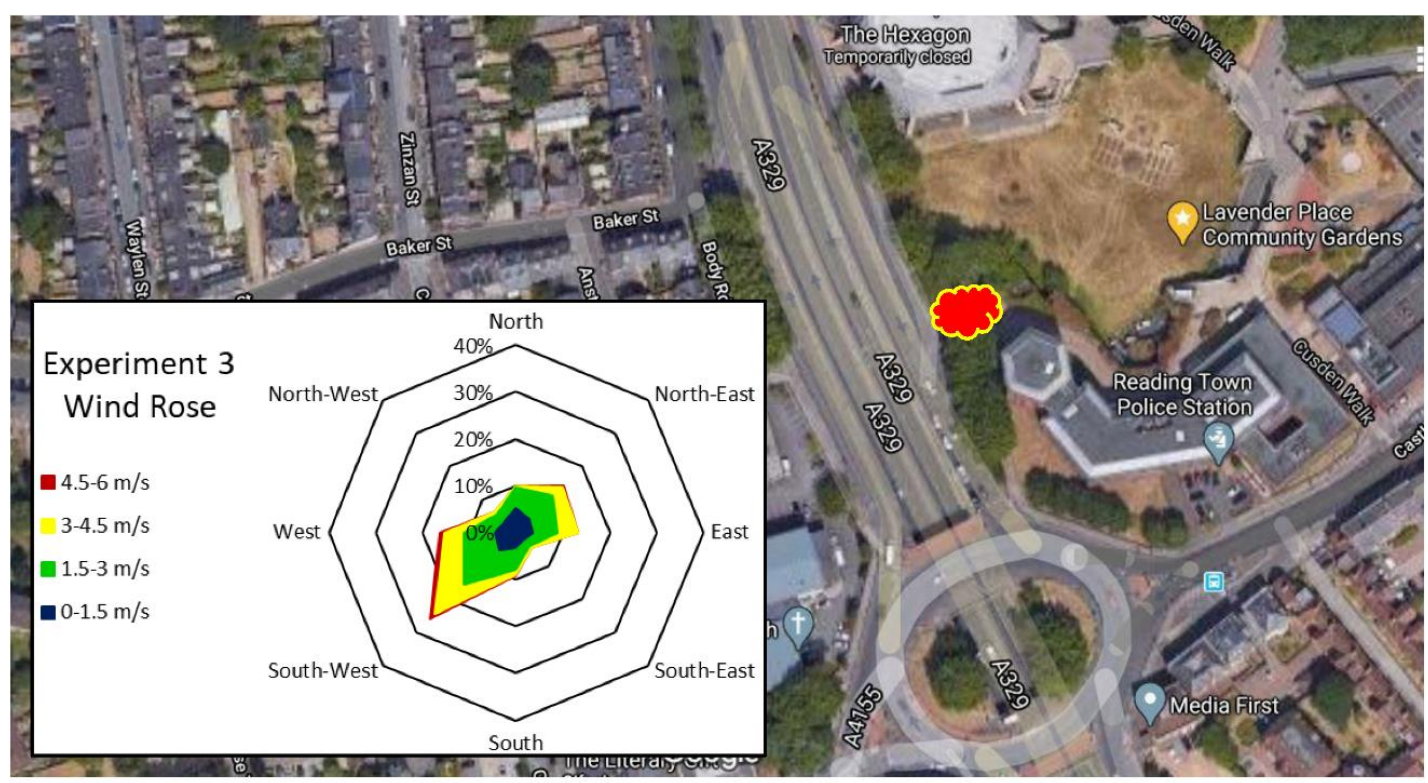

Figure 3. Location of the major-road sampling site for Experiment 3, and corresponding wind rose indicating prevailing wind conditions a month prior to sampling. This site corresponds to red location marker 2 in Figure 1. 


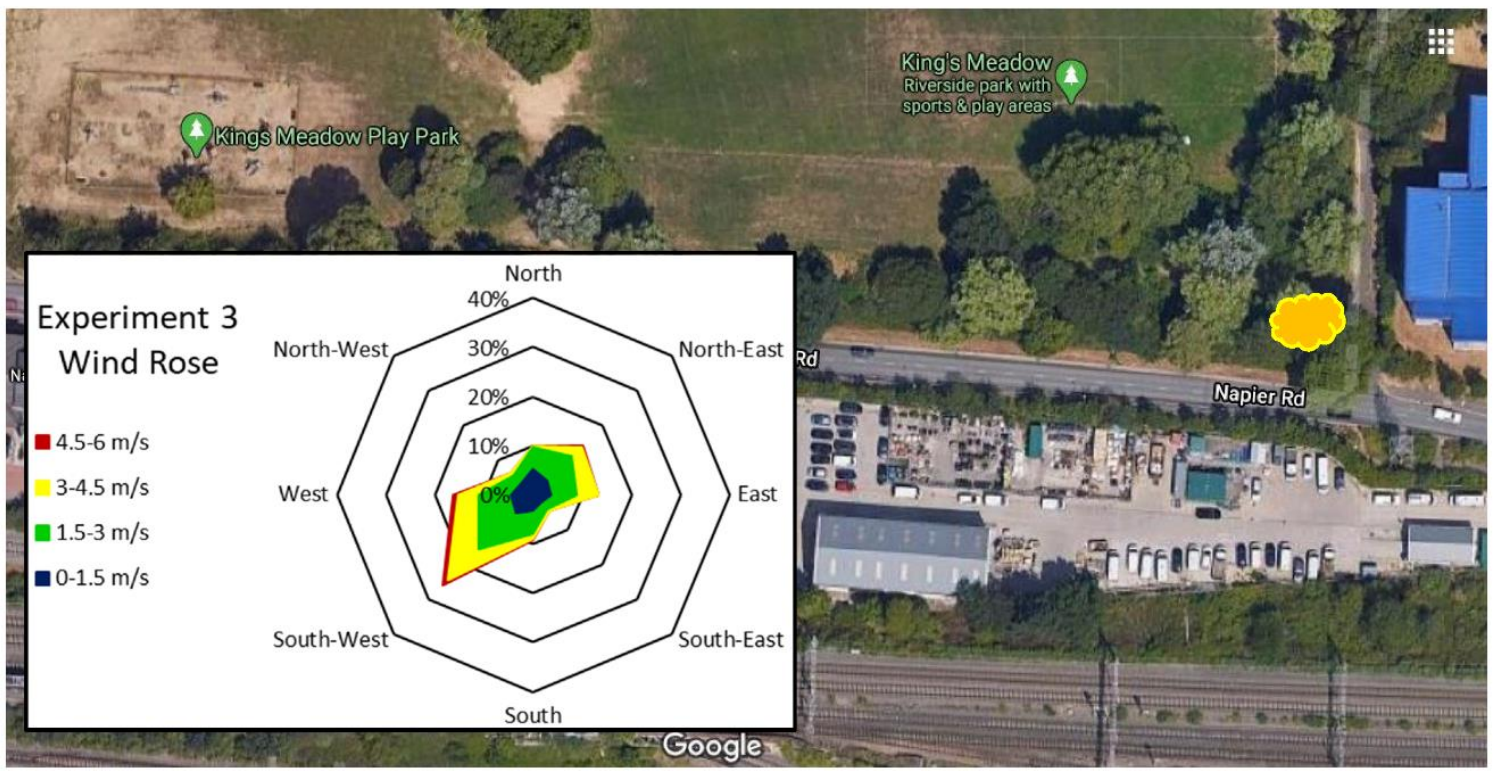

Figure 4. Location of the minor-road sampling site for Experiment 3, and corresponding wind rose indicating prevailing wind conditions a month prior to sampling. This site corresponds to orange location marker 3 in Figure 1.

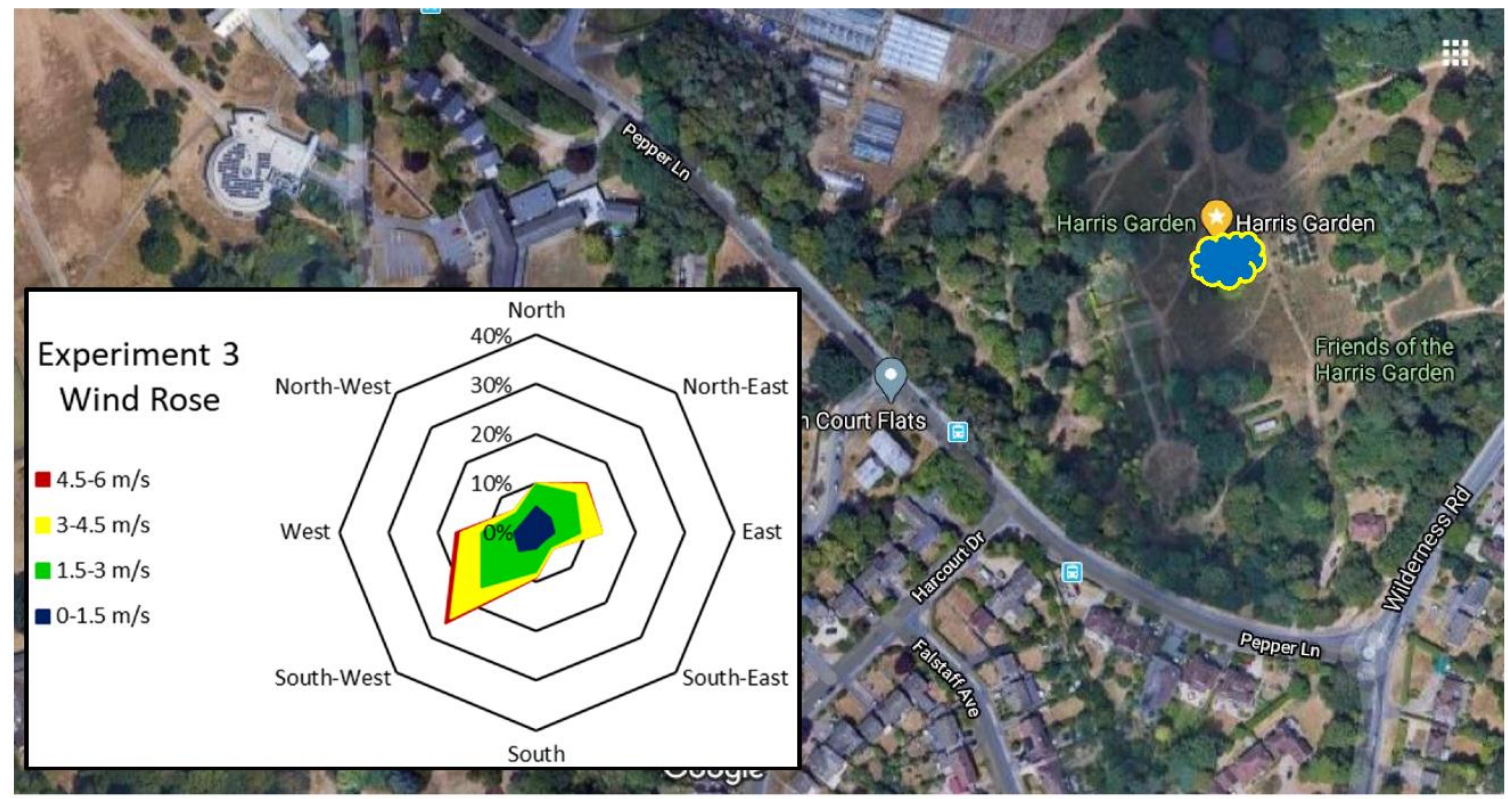

Figure 5. Location of control ('no traffic') sampling site for Experiment 3, and corresponding wind rose indicating prevailing wind conditions a month prior to sampling. This site corresponds to blue location marker 4 in Figure 1.

Eight years of meteorological data, incorporating at least five years of data prior to each study period (so 2011-2016 for Experiments 1 and 2, and 2011-2019 for Experiment 3), were sourced from Reading University Atmospheric Observatory (National Grid Reference (SU739719, Latitude 51.44136 ${ }^{\circ} \mathrm{N}$, Longitude $0.93807^{\circ} \mathrm{W}$, Altitude $66 \mathrm{~m}$ above MSL) (https://research.reading.ac.uk/meteorology/ atmospheric-observatory/atmospheric-observatory-data/). These were analysed to determine prevailing wind speed and direction in the study area (Figure 1). Hourly data for approximately a month prior to the sampling date of each experiment were obtained and used to confirm weather conditions just prior to and at the time of the study (see Figures 2-5, and Table A1). 
Traffic flow data was sourced from the Department for Transport (DfT) datasets, which record the average number of vehicles passing junction to junction on major road networks for each local authority [37]. The latest available statistics are for 2018, and show that an average of 47,000 motor vehicles per day passed through the junction closest to our 'major road' sampling sites, along with just over 6000 per day at the 'minor' road site. The 'no road' site was within the University of Reading grounds, in the Harris Garden, at least $100 \mathrm{~m}$ away from any traffic (which in itself would be on a 'minor' road) and surrounded by extensive other vegetation.

\subsection{Sampling and Analysis Approaches}

Experiments were performed in three stages: in July and October 2016 and in June-July 2019. A summary of locations, plant species used, particle determination methodologies employed, and sampling times is provided in Table 1.

Two of the hedge species utilised in the study are deciduous or semi-deciduous, and in order to be able to objectively compare their effectiveness against the other species it was necessary for them all to be in a similar physiological state. Consequently, the experiments were carried out during periods of maximum leaf area, and peak physiological activity associated with summer. Experiments 1 and 2 were carried out in the same location on containerized plants, and Experiment 3 was carried out on a nearby location on a hedgerow planted into the ground (Table 1). Each of the experiments was preceded by preliminary testing of the techniques (typically over a period of 2-3 weeks before experimental sampling) and the locations, to establish the quantities of leaves required to achieve reproducible results, and to finalise experimental protocols. Additionally, prior to setting up Experiment 3, we tested the species already in position for experiments 1 and 2 for their capacity for PM capture, determined by gravimetric method (data not shown). That enabled us to identify the species we wanted to test further (namely Cotoneaster and Crataegus, the highest and lowest accumulators gravimetrically in the pre-tests), in the practical context, planted as a roadside hedge. Our rationale in changing the locations for the Experiment 3 compared to Experiments 1 and 2 was in seeking as close as possible a 'real-life' planting scenario. The rationale for planting choice is detailed below.

\subsection{Plant Material}

In Experiments 1 and 2, four-year-old plants of five hedge species (Table 1), grown individually in 101 containers, with John Innes no 3 compost (7:3:2 sterilised loam:peat:coarse sand $v / v$, Westland, Dungannon, UK), were used. Plants were obtained from Hillier Nurseries (Romsey, Hampshire, UK). Plants of each species (2 specimens per species) were positioned on a pavement edge, $1 \mathrm{~m}$ away from the major road. Plants were arranged in a way to visually resemble a hedge in the ground and the canopies were clipped in a hedge like form to create a barrier approx. $1.6 \mathrm{~m}$ tall and $1.2 \mathrm{~m}$ deep. Plants were arranged as a continuous row consisting of two blocks (each block containing each of the five species within it). Plants within the block were randomly distributed. Plant species in Experiments 1 and 2 were chosen to represent a range of leaf shapes and textures (hairy, smooth, small, large, etc., Table 2).

To prepare material for Experiment 3 in a 'major road' scenario, six-year-old plants of Crataegus monogyna (common name: Hawthorn), Cotoneaster franchetii (common name: Franchet's cotoneaster) and Thuja plicata (common name: Western Red Cedar) were transplanted in November 2018 from 101 containers into the ground within Lavender Place Community gardens, Reading (UK). Plants were $9 \mathrm{~m}$ away from the major road, planted in blocks of three plants of the same species, repeated 3 times, creating a $25+\mathrm{m}$ strip. Chosen species represented the strongest and weakest 'accumulators' (Cotoneaster and Crataegus) with the addition of Thuja which was hypothesized from the literature to have leaf properties required for enhanced particles' deposition. Additionally, this site contained plants of Acuba japonica already established in situ which we considered as an example of leaf type which from the literature would likely be weaker for particles' deposition (Table 3). This combination of species was also chosen to enable a comparison, within Experiment 3, of different locations, with a range of associated traffic intensities. 
Table 2. Leaf properties of the hedge species used in the experiments.

\begin{tabular}{ccc}
\hline Hedge Species & Leaf Image & Leaf Properties \\
\hline Acuba japonica & Ovate, smooth, large leaves with serrated \\
edges. Evergreen.
\end{tabular}

Cotoneaster franchetii

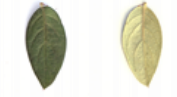

Obovate, small, hairy leaves, particularly abaxially. Evergreen.

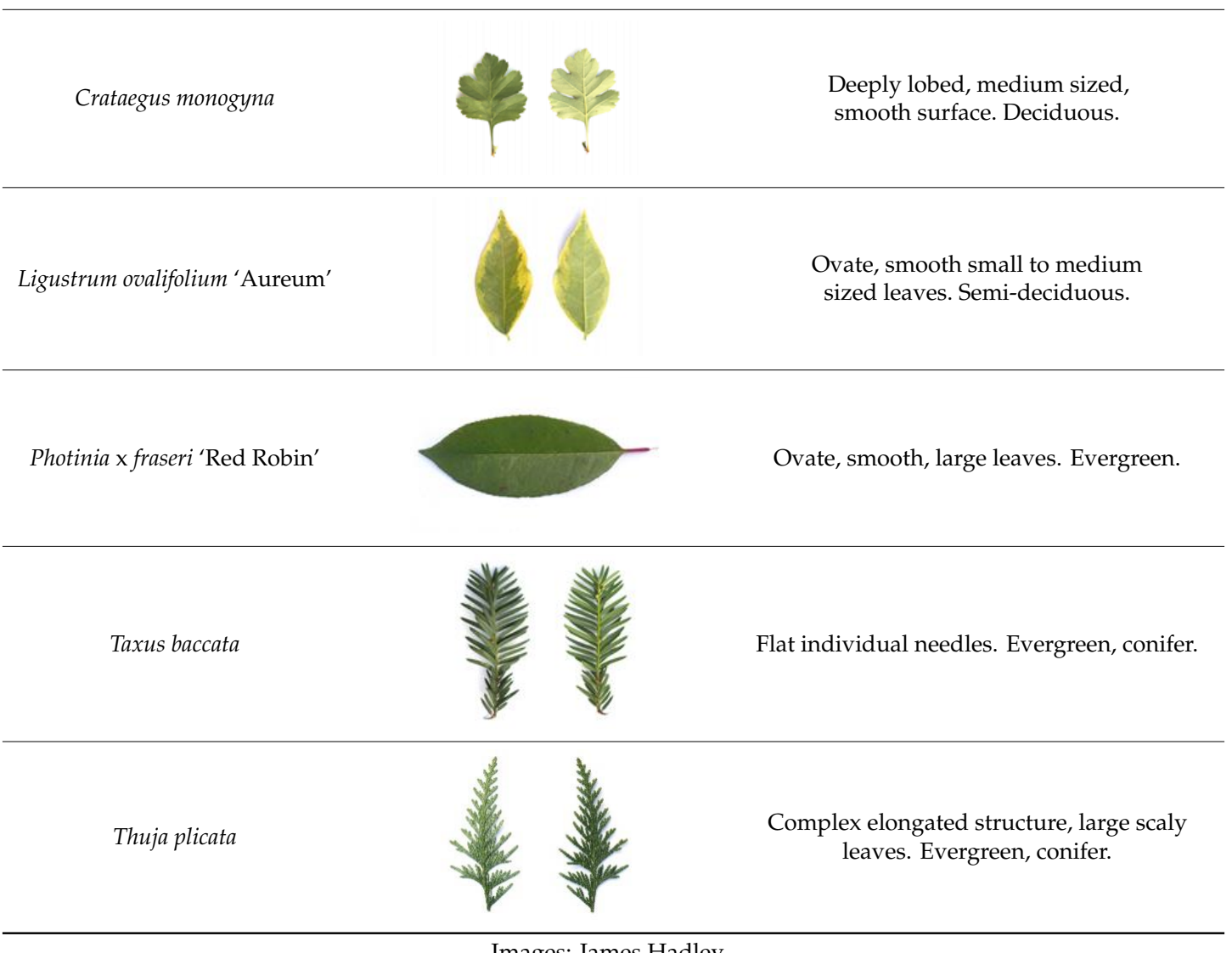

Images: James Hadley.

Table 3. Hedge species sampled in Experiment 3, along with the associated detail of sampling locations.

\begin{tabular}{ccccc}
\hline \multirow{2}{*}{ Hedge Species } & Sampling Site & $\begin{array}{c}\text { Distance from Road } \\
\text { (m) }\end{array}$ & \multicolumn{2}{c}{ Hedge Dimensions (m) } \\
\cline { 3 - 5 } Acuba japonica & Major rd & 1 & Height & Width \\
'Crotonifolia & Minor rd & 7 & 0.5 & 1 \\
& No road & $>100$ & 1.5 & 2 \\
Crataegus monogyna & Major rd & 9 & 2 & 2 \\
& Minor rd & 6 & 1.2 & 1 \\
& No road & $>100$ & 2 & 2 \\
\hline \multirow{2}{*}{ Cotoneaster franchetii } & Major rd & 9 & 1.2 & 1.5 \\
& Minor rd & 6 & 2 & 1.5 \\
\hline Thuja plicata & No road & $>100$ & 2 & 2 \\
\hline
\end{tabular}


Plants for the 'minor' and 'no road' scenarios in Experiment 3 were those already previously growing in those locations. Sites were chosen because they all contained specimens of Acuba japonica, Crataegus monogyna and Cotoneaster franchetii growing in close proximity and at the same (or in cases of 'no road' - similar) distance from the road. Plants were visually in good health and were growing in a hedge-like form. Detail of leaf images and properties in Table 2 and plant dimensions within a hedge is provided in Table 3 .

\subsection{Analysis of the Collected Leaf Samples}

\subsubsection{GC-MS Determination of Heavy Metals' Concentrations within Leaf Tissue}

Two plants per species, all in 10 L containers, were brought onto the location in June 2016 and distributed along the roadside in two continuous blocks (each block containing each of the five species within it). Plants within the block were randomly distributed. Prior to bringing to the experimental roadside site, plants were maintained at the University of Reading Glasshouses grounds (approximately $200 \mathrm{~m}$ away from a minor road in a traffic-free part of the campus) and immediately prior to transporting were 'hosed down' with running mains water to ensure that the canopies were as free of particles as was reasonably possible before commencing a roadside experiment. Leaf samples were taken for the analysis of the following heavy metals: $\mathrm{Zn}, \mathrm{Cu}, \mathrm{Pb}$, as well as $\mathrm{Na}$, before leaving the University grounds and then after the plants had been exposed to roadside traffic for 9 days without rain. The duration of the period before roadside sampling was dictated by weather conditions and weather forecast. In this particular experiment the longest period without rain was 9 days, hence sampling at that time point. Four samples $\left(200 \mathrm{~cm}^{2}\right.$ each) (two from each individual plant of each species) were taken. Mature, fully developed leaves were chosen on the branch sections of previous year's growth (i.e., 2-year old wood). Individual samples were collected into paper bags and within $1 \mathrm{~h}$ of sampling placed into a drying oven $\left(70^{\circ} \mathrm{C}\right)$ for $24 \mathrm{~h}$. Dried leaves were then carefully removed from the branches and manually ground (with pestle and mortar) to fine powder consistency before being sent away for elemental analysis. Leaf samples were analysed by the NRM Laboratories (Bracknell, Berkshire, UK) broadly following the approach by Blanusa et al. [15].

\subsubsection{Determining the Numbers of Particles on Leaves Using Scanning Electron Microscopy (SEM)}

The leaf samples from five hedge species were collected from a roadside and off-road scenario to represent the test and control samples respectively. The roadside plants were positioned $1 \mathrm{~m}$ from the road (Table 1) and 'control' plants were housed within the experimental grounds at the University of Reading (approximately $200 \mathrm{~m}$ away from a minor road in a traffic free part of the campus).

Samples were collected at the same time from both the test and control groups of all five species following a 9-day rain free period. At the time of sampling, canopies were still in full leaf and sampled leaves were visually all non-senescent. We were also careful to sample leaves on the same ages of branches (previous year growth). Additionally, four out of five compared species are evergreen so the time of the year will have a limited impact on leaf morphology. Each sample was placed into a separate sealed plastic bag, transported to the Electron Microscopy Laboratory at the University of Reading, and processed within $72 \mathrm{~h}$ of sampling. Samples processed $12-72 \mathrm{~h}$ after the initial sampling were stored in the cold room $\left(4^{\circ} \mathrm{C}\right)$ until microscopy analysis. Five samples were randomly sampled from each of the ten experimental groups (a test and control sample for each of the five hedge species) and cut with a single edge razor blade to achieve approximately $100 \mathrm{~mm}^{2}$ area. The samples were individually mounted with the adaxial surface facing up onto $12.5 \mathrm{~mm}$ diameter aluminium stubs with double-sided adhesive carbon tabs ready for imaging. For Taxus, five individual needles were required to be mounted onto microscope stubs, and that constituted one sample. This was then repeated for five different sets. Three micrographs were captured per sample using the Quanta 600 FEG scanning electron microscope (FEI, Eindhoven, Netherlands) in low vacuum mode with an accelerating voltage of $12.5 \mathrm{kV}$. The micrographs were captured at 250x magnification giving an area of $1 \mathrm{~mm}^{2}$. This was 
completed for all five replicates for each of the ten experimental groups. Following this, an open source image-processing program, 'ImageJ' (www.imagej.net) was used to process the micrographs for ease of subsequent particles' size distribution analysis, by determining the area occupied by each particle. This data was then imported into Microsoft Excel for further analysis. Given the irregular shape of these particles the assumption was made to consider them as perfectly circular to calculate the diameter of each particle. Diameters were calculated and particles separated into the three size classes: $<5 \mu \mathrm{m}, 5 \mu \mathrm{m}<\mathrm{x}<10 \mu \mathrm{m}$ and $>10 \mu \mathrm{m}$. Our approach broadly used the methodology outlined by Song et al. [11].

\subsubsection{Leaf-Washing Experiments (Gravimetric Method)}

The experimental framework for analysing the concentration of airborne PM captured on hedges, was adapted from Leonard et al. [19] and Saebo et al. [22]. Essentially, the protocol entailed sampling $200 \mathrm{~cm}^{2}$ of leaf area (three replicates per species and location, Table 1), which was agitated in $200 \mathrm{~mL}$ of de-ionised water on a laboratory shaker for $10 \mathrm{~min}$ and filtered through a vacuum filtration system. Two size fractions were separated by sequentially using two grades of membrane filters: Whatman grade 40 (retention $8 \mu \mathrm{m}$ and greater) and Whatman 7402-004 (retention 0.2 $\mu \mathrm{m}$ and greater, processing just the filtrate that had already passed though the $8 \mu \mathrm{m}$ filter) (Merck, UK). Filter membranes were dried before filtering (for $60 \mathrm{~min}$ at $70{ }^{\circ} \mathrm{C}$ ), and weighed using a precision analytical balance (Mettler Toledo AE160), before filtration and then again once the particles were filtered and filters dried on the bench to constant weight (i.e., until two consecutive measurements within $1 \mathrm{~h}$ showed the same weight, indicating no further water content). The difference between the two measurements represented the weight of collected particles, which was expressed relative to leaf area from which it was washed off. To determine the total leaf area for each sample, a WinDias Leaf image analysis system was used (Delta-T devices, Cambridge, UK).

\subsection{Statistical Analyses}

To compare plant species for their ability to accumulate/capture pollution, two-way (Experiments 1 and 3, Table 4) and one-way (Experiments 2 and 3, Table 5) analysis of variance (ANOVA) was conducted using GenStat (16th Edition), using a 95\% confidence interval. Variances were checked for homogeneity and values were presented as means with the associated least significant differences of the means (LSD), as well as standard error of the mean (SEoM).

Table 4. Mean mass of particulate matter (in class sizes $\geq 8 \mu \mathrm{m}, 8-0.2 \mu \mathrm{m}$ and total) per leaf area $\left(\mathrm{mg} \mathrm{cm}{ }^{-2}\right)$ of three hedge species (Cotoneaster franchetii, Crataegus monogyna, Thuja plicata) at two positions (front and back of hedge), at a distance of 9 metres from the road. Data are mean values of four samples per species, with associated Standard Errors of the Mean (SEoM) and Least Significant Difference (LSD) of the means.

\begin{tabular}{|c|c|c|c|c|}
\hline Hedge Species & $\begin{array}{l}\text { Sampling } \\
\text { Position }\end{array}$ & $\begin{array}{c}\text { PM, } \geq 8 \mu \mathrm{m} \\
\left(\mathrm{mg} \mathrm{cm}^{-2}\right) \pm \text { SEoM }\end{array}$ & $\begin{array}{c}\text { PM, 8-0.2 } \mu \mathrm{m} \\
\left(\mathrm{mg} \mathrm{cm}^{-2}\right) \pm \text { SEoM }\end{array}$ & $\begin{array}{c}\text { Total PM } \\
\left(\mathrm{mg} \mathrm{cm}^{-2}\right) \pm \text { SEoM }\end{array}$ \\
\hline \multirow{2}{*}{$\begin{array}{l}\text { Cotoneaster } \\
\text { franchetii }\end{array}$} & Front & $0.207 \pm 0.012$ & $0.009 \pm 0.001$ & $0.216 \pm 0.013$ \\
\hline & Back & $0.143 \pm 0.002$ & $0.006 \pm 0.001$ & $0.149 \pm 0.002$ \\
\hline \multirow{2}{*}{$\begin{array}{l}\text { Crataegus } \\
\text { monogyna }\end{array}$} & Front & $0.060 \pm 0.007$ & $0.004 \pm 0.001$ & $0.063 \pm 0.008$ \\
\hline & Back & $0.059 \pm 0.011$ & $0.002 \pm 0.001$ & $0.061 \pm 0.012$ \\
\hline \multirow{2}{*}{ Thuja plicata } & Front & $0.099 \pm 0.012$ & $0.007 \pm 0.001$ & $0.105 \pm 0.012$ \\
\hline & Back & $0.080 \pm 0.007$ & $0.004 \pm 0.001$ & $0.085 \pm 0.007$ \\
\hline LSD & & 0.028 & 0.003 & 0.029 \\
\hline
\end{tabular}


Table 5. Mean particulate matter mass (in class sizes $\geq 8 \mu \mathrm{m}, 8-0.2 \mu \mathrm{m}$ and total) per leaf area $\left(\mathrm{mg} \mathrm{cm}^{-2}\right)$ of Aucuba japonica, Cotoneaster franchetii and Crataegus monogyna at sites with different traffic intensities. Data points are mean values of three samples, with associated Standard Errors of the Mean (SEoM) and Least Significant Difference (LSD) of the means.

\begin{tabular}{|c|c|c|c|c|}
\hline Hedge Species & Location & $\begin{array}{c}P M \geq 8 \mu \mathrm{m} \\
\left(\mathrm{mg} \mathrm{cm}^{-2}\right) \pm \mathrm{SEoM}\end{array}$ & $\begin{array}{c}\text { PM 8-0.2 } \mu \mathrm{m} \\
\left(\mathrm{mg} \mathrm{cm}^{-2}\right) \pm \mathrm{SEoM}\end{array}$ & $\begin{array}{c}\text { Total PM } \\
\left(\mathrm{mg} \mathrm{cm}^{-2}\right) \pm \text { SEoM }\end{array}$ \\
\hline \multirow{3}{*}{ Acuba japonica } & Major rd & $0.050 \pm 0.005$ & $0.003 \pm 0.000$ & $0.053 \pm 0.006$ \\
\hline & Minor rd & $0.020 \pm 0.002$ & $0.002 \pm 0.001$ & $0.022 \pm 0.002$ \\
\hline & No rd & $0.012 \pm 0.001$ & $0.001 \pm 0.001$ & $0.013 \pm 0.002$ \\
\hline LSD & & 0.0112 & 0.002 & 0.0119 \\
\hline \multirow{3}{*}{$\begin{array}{l}\text { Cotoneaster } \\
\text { franchetii }\end{array}$} & Major rd & $0.193 \pm 0.025$ & $0.012 \pm 0.001$ & $0.204 \pm 0.026$ \\
\hline & Minor rd & $0.133 \pm 0.011$ & $0.009 \pm 0.001$ & $0.141 \pm 0.012$ \\
\hline & No rd & $0.103 \pm 0.008$ & $0.005 \pm 0.0003$ & $0.108 \pm 0.008$ \\
\hline LSD & & 0.058 & 0.002 & 0.06 \\
\hline \multirow{3}{*}{$\begin{array}{l}\text { Crataegus } \\
\text { monogyna }\end{array}$} & Major rd & $0.076 \pm 0.005$ & $0.004 \pm 0.001$ & $0.079 \pm 0.006$ \\
\hline & Minor rd & $0.051 \pm 0.003$ & $0.003 \pm 0.000$ & $0.054 \pm 0.003$ \\
\hline & No rd & $0.042 \pm 0.009$ & $0.003 \pm 0.000$ & $0.045 \pm 0.009$ \\
\hline LSD & & 0.022 & 0.002 & 0.023 \\
\hline
\end{tabular}

\section{Results}

\subsection{Weather Data}

Weather data assessed for approximately one month prior to each experimental period indicated that the prevailing wind direction was from the South-West in all three cases (Figures 2-5). This suggests that the passage of pollutants from road to hedge would have been aided by the prevailing winds. Detailed weather data was assessed for the 10-day periods prior to each experimental sampling date (see Appendix A). Rain-free ( $<1 \mathrm{~mm} /$ day) periods prior to sampling were 9 days (Exp1), 9 days (Exp2) and 11 days (Exp3) (Appendix A Table A1).

\subsection{GC-MS Determination of Heavy Metals' Concentrations within Leaf Tissue}

While leaf samples were tested for the presence of four elements $(\mathrm{Zn}, \mathrm{Cu}, \mathrm{Pb}, \mathrm{Na})$, it was only in $\mathrm{Pb}$ samples that there was a significant increase in leaf concentrations after the exposure to roadside pollution (F pr. < 0.001). Concentration of $\mathrm{Pb}$ was highest in Cotoneaster leaf samples-it increased 3-fold after the 9-day exposure to roadside conditions (from approx. $0.47 \mathrm{mg} \mathrm{kg}^{-1}$ to $1.53 \mathrm{mg} \mathrm{kg}^{-1}$, LSD $=0.248$, Figure 6). In Taxus however, there was only a 2-fold increase in roadside samples compared to the control (from 0.33 to $0.61 \mathrm{mg} \mathrm{kg}^{-1}$ ) (Figure 6).

For other measured elements, there were no significant differences in leaf concentrations between the two sampling sites/times (data not shown). There were however species differences in the extent of elements' accumulation in the leaves. Cotoneaster had highest leaf $\mathrm{Cu}$ concentration, $8.15 \mathrm{mg} \mathrm{kg}^{-1}$, and Photinia 'Red Robin' lowest, $1.80 \mathrm{mg} \mathrm{kg}^{-1}$ (LSD = 2.794). Ligustrum, followed by Cotoneaster, accumulated the most $\mathrm{Zn}$, with Photinia having the lowest-50.0, 36.0, and $20.0 \mathrm{mg} \mathrm{kg}^{-1}$ respectively, $\mathrm{LSD}=5.08$ (data not shown). 


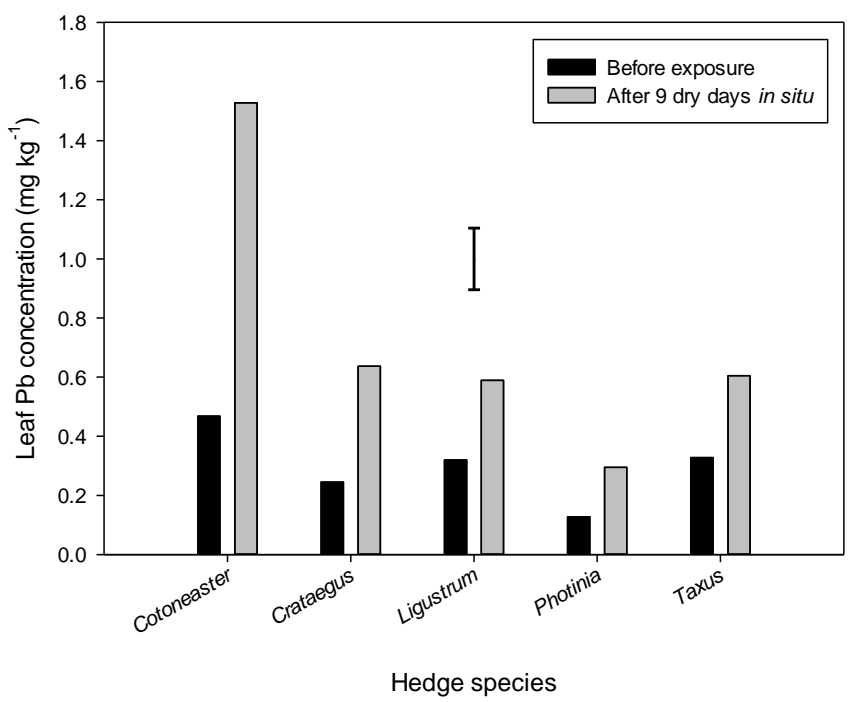

Figure 6. Mean lead $(\mathrm{Pb})$ leaf concentration before and after a 9-day exposure to roadside traffic, in rain-free conditions for the five studied hedge species. Bars are mean of four replicates per species. Vertical error bar represents Least Significant Difference (LSD) of the means (LSD $=0.248$ ).

\subsection{Determining the Numbers of Particles on Leaves Using Scanning Electron Microscopy (SEM)}

Microscopic analysis of leaves prior to exposure to street level pollution showed near 0 counts of particles and no significant species differences (data not shown). Once the plants were exposed to street-level pollution for 9 rain-free days, there were significant differences in the numbers of particles recorded on different species in two of the three class sizes we studied (i.e., $>10 \mu \mathrm{m}$ and $5<\mathrm{x}<10 \mu \mathrm{m}$, $\mathrm{F}$ pr $<0.001$ and 0.028 , respectively). In the $>10 \mu \mathrm{m}$ class size we recorded smallest number of particles on Cotoneaster ( 76 particles per $\mathrm{mm}^{2}$ ), compared to all other species (where similar numbers of particles were deposited, on average 145 particles per $\mathrm{mm}^{2}$ ) (Figure 7). In the $5<\mathrm{x}<10 \mu \mathrm{m}$ class size, Taxus accumulated significantly more particles (356 particles per $\mathrm{mm}^{2}$ ) than Photinia 'Red Robin' (243 particles per $\mathrm{mm}^{2}$ ) and Cotoneaster, with 198 particles per $\mathrm{mm}^{2}$ (Figure 7). There were no significant differences between species in $<5 \mu \mathrm{m}$ class size (Figure 7).

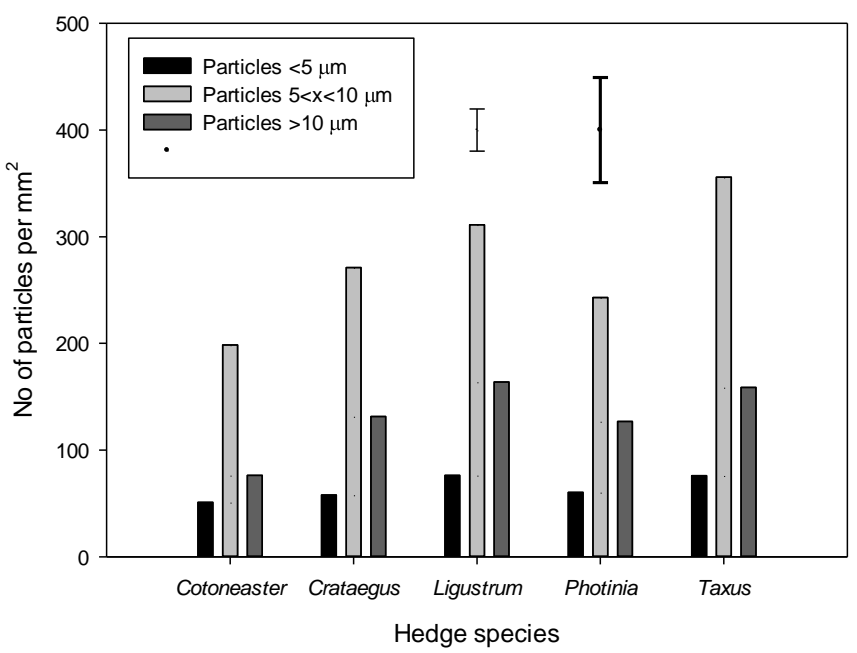

Figure 7. Mean number of particles on leaf surfaces (particles per $\mathrm{mm}^{2}$ ) after a 9-day exposure to roadside traffic, in rain-free conditions for the five tested hedge species. Bars are mean of five replicates per species. Vertical error bars represent Least Significant Difference (LSD) of the means where the means were significantly different $(<5 \mu \mathrm{m}$ no significant differences, $5<\mathrm{x}<10 \mu \mathrm{m} \mathrm{LSD}=39.44,>10 \mu \mathrm{m}$ fraction LSD $=98.57$ ). 


\subsection{Leaf-Washing Experiments (Gravimetric Method)}

There were significant species differences in the mass of particles deposited on the leaves in hedgerows planted $9 \mathrm{~m}$ from a major road (for both $\geq 8 \mu \mathrm{m}$ and $\geq 0.2 \mu \mathrm{m})(\mathrm{F} \mathrm{pr}<0.001, \mathrm{LSD}=0.029$ ). Overall, Cotoneaster franchetii captured the most particulate matter mass per leaf area (up to $0.216 \mathrm{mg} \mathrm{cm}^{-2}$ ), approx. 3-fold more total PM concentration than Crataegus monogyna and nearly 2-fold more than Thuja plicata (Table 4). Crataegus monogyna captured the least particulate matter $\left(0.063 \mathrm{mg} \mathrm{cm}^{-2}\right.$ on average).

Hedge depth significantly influenced the concentration of PM only in Cotoneaster. Mean weight of $\mathrm{PM} \geq 0.2 \mu \mathrm{m}$ was $37 \%$ greater at the front of the hedge (exposed to road traffic) than behind (facing pedestrian area), and $44 \%$ more for $\mathrm{PM} \geq 8 \mu \mathrm{m}$ (Table 4 ).

There were statistically significant differences in the mean mass of particulates between the major road and minor road and also between the major road and no road for $P M \geq 8 \mu \mathrm{m}$ for all plant species (Table 5). There was no statistically significant difference between the mean values for the minor road and no road for PM $\geq 8 \mu \mathrm{m}$ on any of the tested species (Table 5). Mean total PM mass was higher for the major road compared to the minor road by $+31 \%$ (Cotoneaster franchetii), $+32 \%$ (Crataegus monogyna), and $+59 \%$ (Aucuba japonica). The difference was even more pronounced in comparison to 'no road': $+47 \%$ (Cotoneaster franchetii), $+44 \%$ (Crataegus monogyna), and $+75 \%$ (Aucuba japonica). Particles in the $8-0.2 \mu \mathrm{m}$ range only showed a statistically significant difference between the sites for Cotoneaster $(\mathrm{F} \mathrm{pr}=0.02)$.

\section{Discussion}

Presented research started as a quest to find a rapid and cost-effective way to reliably assess plant (specifically hedges') species differences in their capability to remove urban airborne particulate pollutants. The work within this project developed in a two-pronged way: to compare the methodologies to determine pollutants' capture/removal (GC-MS, microscopy and gravimetric method) and then also to evaluate if the plant species' ranking, in terms of their ability to remove pollutants, remains broadly the same irrespective of the method used. Additionally, we investigated the impact of traffic intensity on the roads adjacent to studied hedges, on the species' capacity for PM capture.

\subsection{Comparisons of the Methodologies}

The GC-MS approach of analysing plant material for the presence of various metals (including heavy metals) and other chemical elements was widely used in biomonitoring studies following temporal changes in elements' concentration, e.g., in various urban settings [14,38]. Using control, less polluted, sites for comparison with high traffic areas does enable, to an extent, the assessment of pollutant loads in two areas, but it does not discriminate between pollutants deposited on leaf surfaces and those taken up into leaf tissues through uptake from soil. Under the conditions of our experiment, only one out of the four studied elements (namely $\mathrm{Pb}$, lead) was found in higher leaf concentration after the plants' exposure to road traffic for nine days compared to day 0. Also, our day 0 data show that there were species differences in the concentration of different elements in the leaves, with some species being highest accumulators of one element, but not of another. That leads to the question of which element should then be used as a 'tracer' for plant species comparison and ranking? It is also possible that, in younger plantings, the exposure to different elements (e.g., in production, in nurseries) would impact the initial elemental concentrations, which additionally complicates the process of ascertaining plant species differences. In situations where it was important to discriminate and compare the overarching species ability to remove airborne particulate pollutants, the use of GC-MS approach would therefore be limited. It might be applicable, however, if the focus was specifically on a single element which may be a concern in an area (e.g., $\mathrm{Pb}$ in a proximity to a lead-acid battery factory, [39]) and the starting/control element leaf concentrations were similar between the species being compared. 
A number of studies have used microscopic analysis, quoting it as the most direct way of assessing particle number and sizes on the leaf surface (e.g., [11-13]). We agree with this notion in principle, but the microscopic analysis in the context of our chosen species presented us with challenges of accurately analysing hairy leaves in particular. This was manifested in leaf hairs on Cotoneaster obscuring individual particles in some fields of vision, so that the accurate determination of particle sizes, and even numbers, was difficult in some cases. While this can be mitigated in a science research context, with careful adjustments to the fields of vision and increased levels of replication, in the situation, when rapid screening of a number of species is required for various practical purposes, this is unlikely to be feasible.

Leaf washing using distilled or deionised water (and subsequent weighing of the washed and filtered PM) as a method of choice is open to criticism. This could be because accumulation of PM on leaf surfaces could be overestimated by including structures such as leaf hairs in the measurements following dislodging after vigorous washing. Additionally, it had been suggested that water washing (soaking, then rinsing leaves with deionized water) does not remove all the deposited PM [40]. It had also been suggested that in situations where the primary experimental aim is to achieve detailed understanding of the processes involved in PM deposition at the leaf level, simultaneous use of multiple methods to elucidate deposition processes and outcomes may be fully justified [20]. However, under the circumstances of our experimental needs, we found that, when collecting samples in the short interval of time and similar environmental conditions, a simple gravimetric approach gave us the opportunity to screen rapidly, cheaply, and with relatively little technical equipment. This method, in our mind, has promise in the situations when the general species comparison for PM removal capacity is required. This approach will have limitations with particles in the PM2.5 range and smaller, due to their low weight where the method may not be sufficiently sensitive unless very large leaf samples are collected and processed.

\subsection{Hedge Species Differences and Links with Leaf Structural Characteristics}

GC-MS analysis confirmed that studied hedge species differed in the uptake of selected elements but also that species 'ranking' for the elements' uptake changed depending on the element in question. Only for $\mathrm{Pb}$, however, were we able to measure a 'before' and 'after' exposure difference suggesting that in a short experiment (nine days between two sampling occasions, due to unsettled rainy sampling weather) hairy-leaved Cotoneaster accumulated most $\mathrm{Pb}$ compared to the control, and smooth-leaved Photinia-least. For all other measured elements, species choice made no difference to the amount of element sequestered from (presumably) traffic-related pollution sources. The microscopy approach also revealed species differences, with Taxus needles attracting most PM in all size classes and Cotoneaster least. Smooth-leaved Photinia also showed lower capacity for capturing of particles $<10 \mu \mathrm{m}$. However, the difficulty in discriminating particles on hairy leaves under the SEM may have led to underestimation of PM deposition on Cotoneaster. The gravimetric method employed in Experiment 3 showed that Cotoneaster accumulated most total PM per unit leaf area and smoother-leaved Crataegus least. A convincing range of literature over the last decade and beyond suggests that features such as leaf hairs and ridges increase PM capture across a range of PM diameters (e.g., [19,31]). Consequently, this leads us to question the validity of our own microscopic examinations in Cotoneaster. More detail is emerging in recent research investigating the importance of the density, orientation, and length of leaf hairs, as well as their prevalence on upper or lower epidermis [32]. It had been suggested that species that are hairy primarily on abaxial surfaces may be less effective in PM deposition for larger size fractions [31]. It had also been posited that a minimum hair density may need to be reached before it significantly contributes toward increased PM deposition [41].

\subsection{Location}

The distance of a sampling location from the major road influenced the quantity of accumulated PM on leaf surfaces. This was the case for the most efficient hedge species in our experiment, 
hairy-leaved Cotoneaster, where lower PM concentration was recorded at the back of the hedge compared to the road-facing side. This effect was however not picked up for the other two studied species under the conditions of our experiment, suggesting that in less effective species a greater hedge depth may be required to achieve measurable reduction in particles' concentration on the two sides of the hedge. However, factors like increased canopy density and larger leaf area will also play a part; plant management strategies such as pruning could be used to increase the 'capacity' of species to attract PM via deposition.

The traffic intensity (heavy, low, or absent) clearly also plays a part in the how much airborne PM will be generated at a particular location. Data from our Experiment 3 supported this notion in that a significantly higher total concentration of particles, measured gravimetrically, was recorded on hedges next to a major road, compared to 'minor' or 'no road' scenarios. Under the conditions of our experiment, we did not, however, record significant difference in PM collected on leaf surfaces between 'minor' and 'no road' situations. This suggests some sort of threshold of traffic/pollutants is required before planting choice begins to make a difference to how much PM is removed by deposition onto leaves.

\section{4. 'Bigger Picture' View}

Our findings confirm that, on a plant scale, features such as leaf and canopy properties (shape, size, leaf hairiness) influence the extent of particulates' deposition on a hedge. Cotoneaster -with hairy, small ovate leaves-attracted the greatest particulate deposition ( $\mathrm{g} \mathrm{m}^{-2}$ of leaf area). Results also suggest that a significant extent of coverage and hedge depth is required, particularly to reduce the concentration of fine particles and in species with smaller inherent capacity for particulates' capture. This was evidenced in similar total concentrations of particulates we detected at the front and back of Crataegus and Thuja even when the hedge depth was in the $1.5 \mathrm{~m}$ range, suggesting that a greater hedge depth (and/or density, achieved either through crown pruning to encourage branching, or denser planting) is needed to reduce concentrations of fine particles. In a more efficient Cotoneaster, however, concentration of particles was reduced at the back compared to the front of the hedge. While our work only considered particulate capture per unit leaf area (i.e., we assumed that all hedges had same leaf area), it is clear that the overall canopy leaf area will impact actual capture. For example, increasing the size of a less efficient hedge could help boost its capture potential. Admittedly, assessing the quantities (numbers or weight) of particulates on leaf surfaces is just one of the indicators of a species' capacity for air quality mitigation. Some species may retain particles through stomatal or cuticular uptake, or intercept but then shed PM onto the ground (e.g. [42]). Additionally, developing particle size distribution profiles for various species is beneficial, due to smaller fractions ( $\mathrm{PM}_{2.5}$ and below) having typically greater health impacts (e.g. [18]). The impact of hedge density on the filtering and dispersal of particles around the hedge would need to be investigated in the future. For example, would a very dense specimen of an 'effective' hedge species be actually less beneficial (due to its diverting/barrier effect on air flow) than a nominally less 'effective' hedge species which allows more air flow through it? While further fine-tuning of the concept of the best planting choices and their management is inevitable, in our view the current state of knowledge points to the overwhelmingly beneficial effect of hedges in reducing PM concentrations at roadsides.

Our findings suggest that planting choice makes significant difference to the extent of capture only on major roads, where the pollutant concentrations are highest. Our findings support the recommendation of a limited number of specific hedge species that would provide optimum services for urban environments (in the sense of more engineered green infrastructure solutions to mitigate air pollution) on major roads, while giving the domestic/sub-urban gardeners on less busy roads more freedom to select a wider range of species. 


\subsection{Limitations of the Study}

With our experiments being set up in situ, in various outdoor settings, the biggest challenge to the measurements of pollution accumulation was natural precipitation. Other studies investigating deposition of airborne pollutants and uptake of chemical elements in situ have reported a very wide range of rain-free days prior to sampling (e.g., from four to 30, [11,43]). While, clearly, longer periods of exposure would provide an increased accumulation of pollutants, the local weather conditions in the years when we carried out the experiments allowed only for 9-11-day rain-free periods. As one of the foci of our experiments was species to species comparison, we felt that this was possible even with shorter exposure, as all species in the experiments were exposed for the same duration of time and there were clear differences (in Experiments 1 and 2) between 'clean' control samples and those collected by the roadside, even after nine days.

Finally, our approach assumed that fine particles move horizontally through the hedge from roadside to interior. However, if there is particle deposition from above the hedge downwards, this may explain why the captured PM amounts were not always significantly correlated with depth into the hedge. Sampling along a vertical transect in future campaigns might provide some clarification on this issue.

\section{Conclusions}

Our experiments focused on a comparison of techniques, plant species, and their leaf characteristics, and the importance of those for PM capture in urban locations with a range of traffic intensities. We have found the gravimetric approach the fastest and most cost-effective to process relatively large numbers of samples. We confirmed the importance of leaf characteristics such as hairiness and roughness in maximising capture of particulates. More efficient species, such as Cotoneaster, required a smaller depth of a hedge $(1.5 \mathrm{~m})$ to achieve a reduction of particulate concentration at the back of the hedge compared to the roadside. Species choice made a significant difference to the extent of particulates' capture only on major roads, where the pollutant concentrations are highest, but not on a minor or 'no road' scenarios. This suggests that a threshold of traffic/pollutants is required before species choice may begin to make a difference.

Author Contributions: Conceptualization, T.B., Z.J.Q. and M.B.G.; data collection: T.B., A.K., J.H., and Z.J.Q.; methodology, T.B., A.K., Z.J.Q. and M.B.G.; technical support, J.H.; data analysis, T.B., Z.J.Q., and M.B.G.; writing—original draft preparation, T.B.; writing—review \& editing, M.B.G., A.K., and Z.J.Q.; All authors have read and agreed to the published version of the manuscript.

Funding: This research received no external funding, but the donation of plant material by Hillier Nurseries is gratefully acknowledged.

Acknowledgments: We are very grateful to Liam Docherty, Michael Dawes, Helen Dominick, Alice Dibley, Val Jasper and Matthew Richardson for technical help in various stages of the project, as well as to Dave Richards and colleagues at the Reading International Solidarity Centre (RISC) for hosting and watering our plants at their premises. Thanks also go to Kevin Hobbs/Hillier Nurseries for the donation of plants for the experiment. Z.J.Q. gratefully acknowledges the support of the Elizabeth Creak Charitable Trust for the award of Clyde Higgs Scholarship for her MSc studies.

Conflicts of Interest: The authors declare no conflict of interest. 


\section{Appendix A}

Table A1. Weather data for 10-day periods prior to each experimental sampling date.

\begin{tabular}{|c|c|c|c|c|c|c|c|c|c|}
\hline Exp. No. & Date & $\mathbf{R} \mathbf{H}_{\max }$ & $\mathbf{R} \mathbf{H}_{\min }$ & $T_{\max }$ & $T_{\min }$ & $\begin{array}{l}\text { Solar Rad } \\
\left(\mathrm{MJ} / \mathrm{m}^{2} / \text { Day }\right)\end{array}$ & $\begin{array}{l}\text { Rain Tot } \\
\text { (mm) }\end{array}$ & $\begin{array}{c}\text { Ave Wind } \\
\text { Spd. } \\
\left(\mathrm{m} . \mathrm{s}^{-1}\right)\end{array}$ & $\begin{array}{c}\text { Median } \\
\text { Wind } \\
\text { Dir. }\end{array}$ \\
\hline \multirow{10}{*}{$\begin{array}{c}\text { Experiment } \\
1\end{array}$} & $02 / 07 / 2016$ & 92.0 & 45.0 & 18.6 & 9.2 & 24.9 & 2.4 & 2.9 & $\mathrm{~W}$ \\
\hline & $03 / 07 / 2016$ & 97.0 & 56.0 & 19.9 & 8.5 & 17.3 & 0.0 & 1.6 & SW \\
\hline & $04 / 07 / 2016$ & 98.0 & 62.0 & 18.7 & 9.3 & 20.2 & 0.0 & 2.3 & SW \\
\hline & 05/07/2016 & 95.0 & 49.0 & 20.1 & 11.6 & 17.5 & 0.0 & 2.2 & NW \\
\hline & 06/07/2016 & 97.0 & 43.0 & 20.2 & 8.2 & 26.8 & 0.0 & 1.2 & W \\
\hline & 07/07/2016 & 85.0 & 60.0 & 21.0 & 13.2 & 20.6 & 0.0 & 2.0 & SW \\
\hline & 08/07/2016 & 92.0 & 57.0 & 21.5 & 14.2 & 13.9 & 0.0 & 3.0 & W \\
\hline & 09/07/2016 & 89.0 & 66.0 & 20.8 & 13.9 & 12.6 & 0.0 & 3.2 & SW \\
\hline & $10 / 07 / 2016$ & 98.0 & 57.0 & 21.3 & 15.4 & 11.5 & 0.6 & 3.7 & SW \\
\hline & $11 / 07 / 2016$ & 91.0 & 58.0 & 20.6 & 13.5 & 10.6 & 0.0 & 3.4 & SW \\
\hline \multirow{10}{*}{$\begin{array}{l}\text { Experiment } \\
\quad 2\end{array}$} & $01 / 10 / 2016$ & 99.0 & 64.0 & 14.9 & 5.7 & 9.1 & 11.0 & 1.1 & $S$ \\
\hline & $02 / 10 / 2016$ & 98.0 & 51.0 & 15.6 & 5.9 & 12.7 & 0.0 & 1.3 & NW \\
\hline & 03/10/2016 & 99.0 & 44.0 & 16.8 & 3.1 & 13.7 & 0.2 & 0.8 & NE \\
\hline & $04 / 10 / 2016$ & 99.0 & 51.0 & 18.4 & 6.6 & 12.3 & 0.0 & 2.2 & E \\
\hline & 05/10/2016 & 93.0 & 47.0 & 16.3 & 5.9 & 12.2 & 0.0 & 2.7 & $\mathrm{E}$ \\
\hline & $06 / 10 / 2016$ & 94.0 & 48.0 & 14.7 & 6.2 & 6.9 & 0.0 & 1.9 & $\mathrm{NE}$ \\
\hline & 07/10/2016 & 95.0 & 74.0 & 14.1 & 10.2 & 2.7 & 0.2 & 1.0 & $\mathrm{NE}$ \\
\hline & $08 / 10 / 2016$ & 95.0 & 71.0 & 15.2 & 10.8 & 4.5 & 0.2 & 1.3 & NW \\
\hline & $09 / 10 / 2016$ & 96.0 & 55.0 & 15.1 & 7.0 & 7.9 & 0.0 & 1.3 & NE \\
\hline & $10 / 10 / 2016$ & 99.0 & 52.0 & 13.3 & 3.6 & 11.0 & 0.0 & 1.2 & NW \\
\hline \multirow{10}{*}{$\begin{array}{c}\text { Experiment } \\
3\end{array}$} & $27 / 06 / 2019$ & 86.0 & 42.0 & 23.7 & 12.6 & 28.7 & 0.0 & 3.6 & $E$ \\
\hline & $28 / 06 / 2019$ & 88.0 & 48.0 & 23.3 & 12.2 & 28.0 & 0.0 & 3.2 & $\mathrm{E}$ \\
\hline & $29 / 06 / 2019$ & 95.0 & 27.0 & 32.1 & 13.9 & 28.8 & 0.0 & 2.4 & SE \\
\hline & $30 / 06 / 2019$ & 89.0 & 53.0 & 22.3 & 13.7 & 22.2 & 0.0 & 2.9 & W \\
\hline & $01 / 07 / 2019$ & 91.0 & 50.0 & 20.0 & 12.2 & 19.3 & 0.0 & 2.7 & NW \\
\hline & $02 / 07 / 2019$ & 87.0 & 44.0 & 20.0 & 10.1 & 21.8 & 0.0 & 1.7 & NW \\
\hline & 03/07/2019 & 79.0 & 36.0 & 22.5 & 11.3 & 30.3 & 0.0 & 1.7 & NE \\
\hline & 04/07/2019 & 93.0 & 36.0 & 24.9 & 9.0 & 29.1 & 0.0 & 0.9 & $S$ \\
\hline & 05/07/2019 & 90.0 & 40.0 & 24.5 & 13.1 & 26.7 & 0.0 & 1.5 & W \\
\hline & 06/07/2019 & 87.0 & 57.0 & 22.9 & 12.9 & 25.3 & 0.0 & 1.7 & NE \\
\hline
\end{tabular}

\section{References}

1. Pope, C.A.; Dockery, D.W. Health Effects of Fine Particulate Air Pollution: Lines that Connect. J. Air Waste Manag. Assoc. 2006, 56, 709-742. [CrossRef]

2. Lelieveld, J.; Evans, J.S.; Fnais, M.; Giannadaki, D.; Pozzer, A. The contribution of outdoor air pollution sources to premature mortality on a global scale. Nature 2015, 525, 367-371. [CrossRef]

3. Maher, B.A.; Moore, C.; Matzka, J. Spatial variation in vehicle-derived metal pollution identified by magnetic and elemental analysis of roadside tree leaves. Atmos. Environ. 2008, 42, 364-373. [CrossRef]

4. Escobedo, F.J.; Nowak, D.J. Spatial heterogeneity and air pollution removal by an urban forest. Landsc. Urban Plan. 2009, 90, 102-110. [CrossRef]

5. Grote, R.; Samson, R.; Alonso, R.; Amorim, J.H.; Cariñanos, P.; Churkina, G.; Fares, S.; Thiec, D.L.; Niinemets, Ü.; Mikkelsen, T.N. Functional traits of urban trees: Air pollution mitigation potential. Front. Ecol. Environ. 2016, 14, 543-550. [CrossRef]

6. Hofman, J.; Bartholomeus, H.; Calders, K.; Van Wittenberghe, S.; Wuyts, K.; Samson, R. On the relation between tree crown morphology and particulate matter deposition on urban tree leaves: A ground-based LiDAR approach. Atmos. Environ. 2014, 99, 130-139. [CrossRef]

7. Tallis, M.; Taylor, G.; Sinnett, D.; Freer-Smith, P. Estimating the removal of atmospheric particulate pollution by the urban tree canopy of London, under current and future environments. Landsc. Urban Plan. 2011, 103, 129-138. [CrossRef]

8. Pugh, T.A.M.; MacKenzie, A.R.; Whyatt, J.D.; Hewitt, C.N. Effectiveness of Green Infrastructure for Improvement of Air Quality in Urban Street Canyons. Environ. Sci. Technol. 2012, 46, 7692-7699. [CrossRef] 
9. Abhijith, K.; Kumar, P.; Gallagher, J.; McNabola, A.; Baldauf, R.; Pilla, F.; Broderick, B.; Di Sabatino, S.; Pulvirenti, B. Air pollution abatement performances of green infrastructure in open road and built-up street canyon environments-A review. Atmos. Environ. 2017, 162, 71-86. [CrossRef]

10. Abhijith, K.V.; Kumar, P. Field investigations for evaluating green infrastructure effects on air quality in open-road conditions. Atmos. Environ. 2019, 201, 132-147. [CrossRef]

11. Song, Y.; Maher, B.A.; Li, F.; Wang, X.; Sun, X.; Zhang, H. Particulate matter deposited on leaf of five evergreen species in Beijing, China: Source identification and size distribution. Atmos. Environ. 2015, 105, 53-60. [CrossRef]

12. Weerakkody, U.; Dover, J.W.; Mitchell, P.; Reiling, K. Quantification of the traffic-generated particulate matter capture by plant species in a living wall and evaluation of the important leaf characteristics. Sci. Total Environ. 2018, 635, 1012-1024. [CrossRef] [PubMed]

13. Weerakkody, U.; Dover, J.W.; Mitchell, P.; Reiling, K. The impact of rainfall in remobilising particulate matter accumulated on leaves of four evergreen species grown on a green screen and a living wall. Urban For. Urban Green. 2018, 35, 21-31. [CrossRef]

14. Monaci, F.; Moni, F.; Lanciotti, E.; Grechi, D.; Bargagli, R. Biomonitoring of airborne metals in urban environments: New tracers of vehicle emission, in place of lead. Environ. Pollut. 2000, 107, 321-327. [CrossRef]

15. Blanusa, T.; Fantozzi, F.; Monaci, F.; Bargagli, R. Leaf trapping and retention of particles by holm oak and other common tree species in Mediterranean urban environments. Urban For. Urban Green. 2015, 14, 1095-1101. [CrossRef]

16. Kumar, R.S.; Rajkumar, P. Characterization of minerals in air dust particles in the state of Tamilnadu, India through FTIR, XRD and SEM analyses. Infrared Phys. Technol. 2014, 67, 30-41. [CrossRef]

17. Hofman, J.; Wuyts, K.; Van Wittenberghe, S.; Brackx, M.; Samson, R. On the link between biomagnetic monitoring and leaf-deposited dust load of urban trees: Relationships and spatial variability of different particle size fractions. Environ. Pollut. 2014, 189, 63-72. [CrossRef]

18. Dzierżanowski, K.; Popek, R.; Gawrońska, H.; Sæbø, A.; Gawroński, S.W. Deposition of particulate matter of different size fractions on leaf surfaces and in waxes of urban forest species. Int. J. Phytoremed. 2011, 13, 1037-1046. [CrossRef]

19. Leonard, R.J.; McArthur, C.; Hochuli, D.F. Particulate matter deposition on roadside plants and the importance of leaf trait combinations. Urban For. Urban Green. 2016, 20, 249-253. [CrossRef]

20. Castanheiro, A.; Hofman, J.; Nuyts, G.; Joosen, S.; Spassov, S.; Blust, R.; Lenaerts, S.; De Wael, K.; Samson, R. Leaf accumulation of atmospheric dust: Biomagnetic, morphological and elemental evaluation using SEM, ED-XRF and HR-ICP-MS. Atmos. Environ. 2020, 221, 117082. [CrossRef]

21. Tiwary, A.; Reff, A.; Colls, J.J. Collection of ambient particulate matter by porous vegetation barriers: Sampling and characterization methods. J. Aerosol Sci. 2008, 39, 40-47. [CrossRef]

22. Sæbø, A.; Popek, R.; Nawrot, B.; Hanslin, H.M.; Gawronska, H.; Gawronski, S.W. Plant species differences in particulate matter accumulation on leaf surfaces. Sci. Total Environ. 2012, 427, 347-354. [CrossRef] [PubMed]

23. Xie, C.; Kan, L.; Guo, J.; Jin, S.; Li, Z.; Chen, D.; Li, X.; Che, S. A dynamic processes study of PM retention by trees under different wind conditions. Environ. Pollut. 2018, 233, 315-322. [CrossRef] [PubMed]

24. Blanusa, T.; Garratt, M.; Cathcart-James, M.; Hunt, L.; Cameron, R.W.F. Urban hedges: A review of plant species and cultivars for ecosystem service delivery in north-west Europe. Urban For. Urban Green. 2019, 44, 126391. [CrossRef]

25. Ottelé, M.; van Bohemen, H.D.; Fraaij, A.L. Quantifying the deposition of particulate matter on climber vegetation on living walls. Ecol. Eng. 2010, 36, 154-162. [CrossRef]

26. Speak, A.F.; Rothwell, J.J.; Lindley, S.J.; Smith, C.L. Urban particulate pollution reduction by four species of green roof vegetation in a UK city. Atmos. Environ. 2012, 61, 283-293. [CrossRef]

27. Tiwary, A.; Williams, I.D.; Heidrich, O.; Namdeo, A.; Bandaru, V.; Calfapietra, C. Development of multi-functional streetscape green infrastructure using a performance index approach. Environ. Pollut. 2016, 208, 209-220. [CrossRef]

28. Weber, F.; Kowarik, I.; Säumel, I. Herbaceous plants as filters: Immobilization of particulates along urban street corridors. Environ. Pollut. 2014, 186, 234-240. [CrossRef]

29. Beckett, K.P.; Freer-Smith, P.H. Taylor G Particulate pollution capture by urban trees: Effect of species and windspread. Glob. Chang. Biol. 2000, 6, 995-1003. [CrossRef] 
30. Muhammad, S.; Wuyts, K.; Samson, R. Atmospheric net particle accumulation on 96 plant species with contrasting morphological and anatomical leaf characteristics in a common garden experiment. Atmos. Environ. 2019, 202, 328-344. [CrossRef]

31. Barwise, Y.; Kumar, P. Designing vegetation barriers for urban air pollution abatement: A practical review for appropriate plant species selection. NPJ Clim. Atmos. Sci. 2020, 3, 12. [CrossRef]

32. Chiam, Z.; Song, X.P.; Lai, H.R.; Tan, H.T.W. Particulate matter mitigation via plants: Understanding complex relationships with leaf traits. Sci. Total Environ. 2019, 688, 398-408. [CrossRef] [PubMed]

33. Peachey, C.J.; Sinnett, D.; Wilkinson, M.; Morgan, G.W.; Freer-Smith, P.H.; Hutchings, T.R. Deposition and solubility of airborne metals to four plant species grown at varying distances from two heavily trafficked roads in London. Environ. Pollut. 2009, 157, 2291-2299. [CrossRef] [PubMed]

34. Mori, J.; Hanslin, H.M.; Burchi, G.; Sæbø, A. Particulate matter and element accumulation on coniferous trees at different distances from a highway. Urban For. Urban Green. 2015, 14, 170-177. [CrossRef]

35. Säumel, I.; Kotsyuk, I.; Hölscher, M.; Lenkereit, C.; Weber, F.; Kowarik, I. How healthy is urban horticulture in high traffic areas? Trace metal concentrations in vegetable crops from plantings within inner city neighbourhoods in Berlin, Germany. Environ. Pollut. 2012, 165, 124-132. [CrossRef]

36. Antisari, L.V.; Orsini, F.; Marchetti, L.; Vianello, G.; Gianquinto, G. Heavy metal accumulation in vegetables grown in urban gardens. Agron. Sustain. Dev. 2015, 35, 1139-1147. [CrossRef]

37. Department for Transport, DfT 'Road Traffic Statistics'. 2018. Available online: https://roadtraffic.dft.gov.uk (accessed on 27 May 2020).

38. Fantozzi, F.; Monaci, F.; Blanusa, T.; Bargagli, R. Holm Oak (Quercus ilex L.) canopy as interceptor of airborne trace elements and their accumulation in the litter and topsoil. Environ. Pollut. 2013, 183, 89-95. [CrossRef]

39. Chen, L.; Xu, Z.; Liu, M.; Huang, Y.; Fan, R.; Su, Y.; Hu, G.; Peng, X.; Peng, X. Lead exposure assessment from study near a lead-acid battery factory in China. Sci. Total Environ. 2012, 429, 191-198. [CrossRef]

40. Liu, J.; Cao, Z.; Zou, S.; Liu, H.; Hai, X.; Wang, S.; Duan, J.; Xi, B.; Yan, G.; Zhang, S.; et al. An investigation of the leaf retention capacity, efficiency and mechanism for atmospheric particulate matter of five greening tree species in Beijing, China. Sci. Total Environ. 2018, 616, 417-426. [CrossRef]

41. Chen, L.; Liu, C.; Zhang, L.; Zou, R.; Zhang, Z. Variation in tree species ability to capture and retain airborne fine particulate matter $\left(\mathrm{PM}_{2.5}\right)$. Sci. Rep. 2017, 7, 1-11. [CrossRef]

42. Zhang, W.; Zhang, Y.; Gong, J.; Yang, B.; Zhang, Z.; Wang, B.; Zhu, C.; Shi, J.; Yue, K. Comparison of the suitability of plant species for greenbelt construction based on particulate matter capture capacity, air pollution tolerance index, and antioxidant system. Environ. Pollut. 2020, 263, 114615. [CrossRef]

43. Weerakkody, U.; Dover, J.W.; Mitchell, P.; Reiling, K. Particulate matter pollution capture by leaves of seventeen living wall species with special reference to rail-traffic at a metropolitan station. Urban For. Urban Green. 2017, 27, 173-186. [CrossRef]

(C) 2020 by the authors. Licensee MDPI, Basel, Switzerland. This article is an open access article distributed under the terms and conditions of the Creative Commons Attribution (CC BY) license (http://creativecommons.org/licenses/by/4.0/). 